\title{
Prognostic role of anti-diabetic drugs in pancreatic cancer: A systematic review and meta-analysis
}

\author{
Lei Zheng ${ }^{1, *}$, Shinan Yin ${ }^{1, *}$, Fenghua Yao $^{2}$, Hua Bai ${ }^{1}$ and Danqing Jing ${ }^{1}$ \\ ${ }^{1}$ Department of Endocrinology, the First Affiliated Hospital of Chinese PLA General Hospital, Beijing, China \\ ${ }^{2}$ Department of Nephrology, the First Hospital Affiliated to the Chinese PLA General Hospital, Beijing, China \\ *These authors contributed equally to this work \\ Correspondence to: Shinan Yin, email: zhenglei_1977@sina.com
}

Keywords: anti-diabetic drug(ADD), metformin, pancreatic cancer, prognosis

Received: March 31, $2017 \quad$ Accepted: April 27, $2017 \quad$ Published: May 09, 2017

Copyright: Zheng et al. This is an open-access article distributed under the terms of the Creative Commons Attribution License (CC-BY), which permits unrestricted use, distribution, and reproduction in any medium, provided the original author and source are credited.

\section{ABSTRACT}

Anti-diabetic drugs (ADDs) have been reported to modify the risk and survival of several malignancies, but whether ADDs affect the prognostic outcomes for pancreatic cancer (PC) patients remains unclear. A systematic literature search was performed for studies published until September 2016 investigating the associations between ADD use and PC survival. Pooled hazard ratios (HRs) with $95 \%$ confidence intervals (CIs) were estimated using the random-effects model. Overall survival (OS) and progressionfree survival (PFS) were set as the main outcomes. Twelve cohorts and two randomized controlled trials (RCTs) for a total of 12,6158 subjects were identified for this metaanalysis. Pooled analysis of cohorts suggested that metformin use was significantly associated with improved OS in PC patients ( $n=11$ studies; pooled HR $0.77,95 \%$ CI 0.68 to 0.87 ), with no increased OS for insulin, sulfonylureas (SU) or thiazolidinedione (TZD) (all $P$ values $>0.05$ ). For OS of PC patient using metformin, this effect remained constant by subgroup analyses and sensitivity analysis by trim and filled method. Metaanalysis of RCTs did not show survival benefits for PC patients $(n=2$; pooled HR 1.20, $95 \%$ CI 0.84 to 1.72). We also did not find significant association between metformin use and PFS in PC patients for cohort studies ( $n=2$; pooled HR $1.22,95 \%$ CI 0.76 to 1.95). Our findings provide evidence in cohort studies that metformin, not other ADDs is associated with impoved OS in PC patients; however, due to limited number of studies investigating other ADDs except metformin, further large-scale studies are warranted to determine this associations.

\section{INTRODUCTION}

Pancreatic cancer $(\mathrm{PC})$ remains the tenth most frequent cancer and the third leading cause of cancerrelated death in develped countries [1,2]. Moreover, most patients survive less than one year after diagnosis. Besides some known factors such as smoking, disease stage, alcohol consumption, chronic pancreatitis, family history, few prognostic factors have been identified [3-6].

Numorous observational studies have reported an obvious protective effect of metformin, a commonly used anti-diabetic drug (ADD) for type 2 diabetes, against risk of several malignancies [7-9]. Moreover, diabetic patients with cancer tend to have worse survival, and some ADDs, such as metformin, have been shown to decrease the mortality among diabetics with cancer [10-12]. Although the mechanism of carcinostasis has not been fully understood, hyperinsulinemia, caused by insulin resistance, may lead to up-regulation of insulin-like growth factor-I (IGF-I) signaling pathway, thus inducing proliferation and invasion of cancer cells and decrease apoptosis [13, 14].

The aim of our study was to investigate whether ADD use affected prognostic outcomes of patients with known diabetes through systematic review and metaanalysis. 


\section{RESULTS}

\section{Description of the included studies}

The initial database search yielded a total of 3326 references for eligibility. After excluding the duplicates and screening the remaining title and abstract, 42 potentially relevant studies were identified for further review. After selection, a total of 14 publications met our inclusion criteria (Figure 1) [10-12, 15-25]. The clinical features of included studies were summarized in Table 1. In summary, 13 studies involving 39261 patients investigated the survival outcomes for patients of metformin use, five for insulin use, two for sulfonylureas (SU) use and two for or thiazolidinedione (TZD) use. The median follow-up time ranged from 0.77 to 12 years. Five studies were carried out in USA, three in Europe and two in Asia. Several cohorts were adjusted for some conventional influential factors, including age, sex, disease stage. Six studies involved PC patients with I-IV disease stages, and two with stage IV. Assessment of methodological quality for cohort studies yielded a score range of 7 to 9 , and 7 of 12 studies had a score of 8 or above (Supplementary Table 3).

\section{Metformin use and PC survival}

The combined hazard ratio (HR) for the overall survival (OS) comparing metformin use versus non-use was $0.77\left(95 \%\right.$ CI 0.68 to $\left.0.87 ; \mathrm{I}^{2}=52.9 \%\right)$ with moderate inter-study heterogeneity $\left(\mathrm{I}^{2}=52.9 \%\right.$ ) (Figure 2 ) for cohort studies. No significant progression-free survival (PFS) benefit was found for cohort studies (HR 1.22; 95\% CI 0.76 to 1.95 ). We also did not find significant survival benefit for randomized controlled trials (RCTs) (HR 1.2, $95 \%$ CI 0.84 to 1.72 ).

We summarized the subgroup analyses for OS in Table 2 to further test potential sources of heterogeneity among certain major clinical characteristics of the included studies. The pooled HRs for the majority of the subgroups did not change significantly stratified by some major study characteristics, including the study design and setting, study country, the number of hospitals, sample size, adjusted variables or Newcastle-Ottawa quality assessment scale. A possible interaction was found in two features (sample size and study country). Results of analyses limited to studies with some of the main variable adjusted (age, sex and tumor stage) are presented in Table 2. For studies with
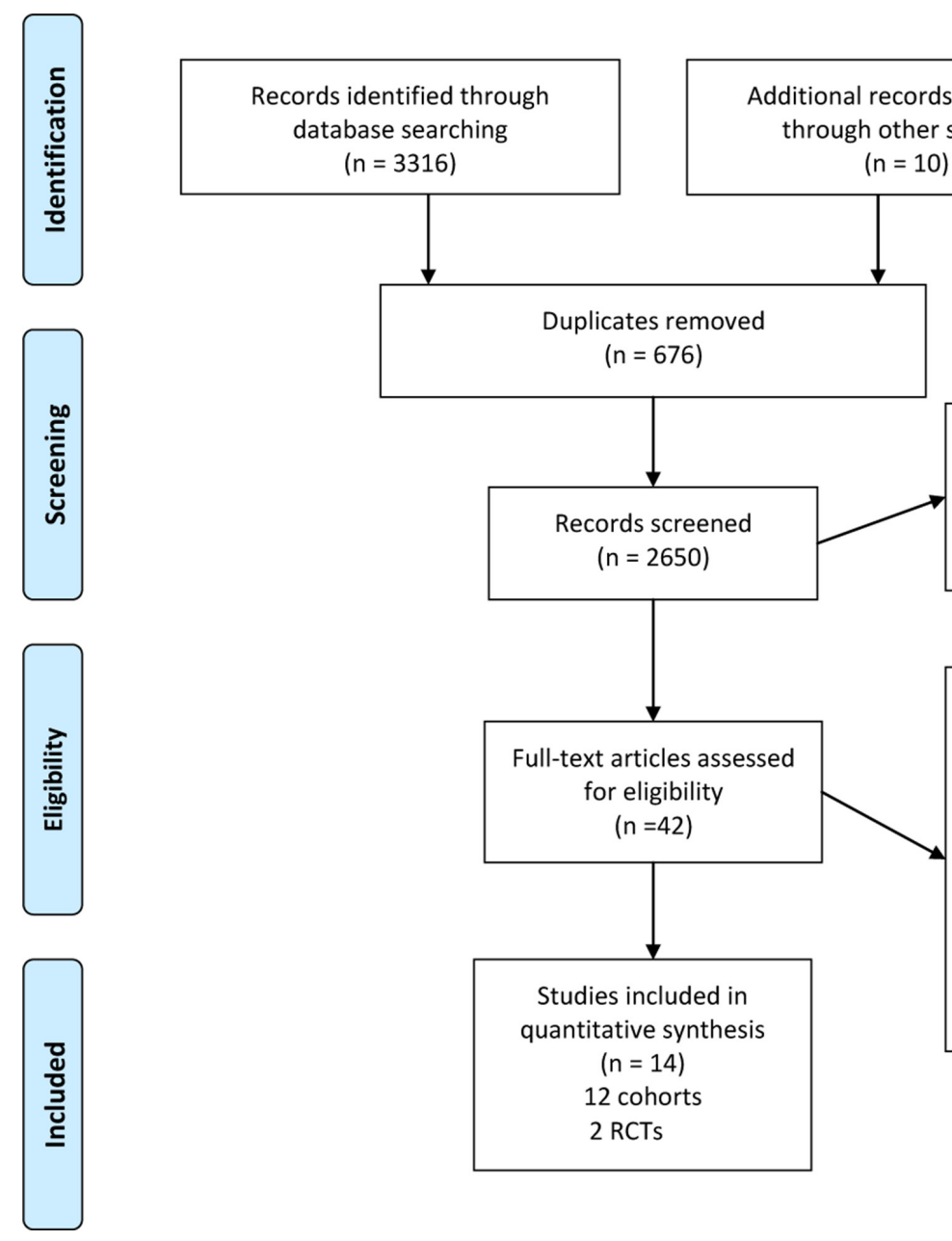

Records excluded ( $n=2608$ ) (irrelevant publications based on title or abstract screening )

Full-text articles excluded $(n=28)$

No relevent outcomes recorded $(n=3)$ Letter, comments, reviews or meta-analyses $(n=12)$ No sufficient data for analysis $(n=6)$ Studies with identical cohorts $(n=7)$

Figure 1: Flow diagram of the study selection. 
Table 1: Characteristics of the included studies on survival outcomes for PC patients taking ADDs

\begin{tabular}{|c|c|c|c|c|c|c|c|c|c|c|c|c|c|c|}
\hline Authors (Year) & Country & Study design & Setting & $\begin{array}{l}\begin{array}{l}\text { No. of hospitals } \\
\text { involved }\end{array} \\
\text { ing }\end{array}$ & Inclusion Year & $\begin{array}{c}\text { Exposure } \\
\text { ascertainment }\end{array}$ & $\begin{array}{l}\text { Outcome } \\
\end{array}$ & $\begin{array}{l}\begin{array}{c}\text { Metformin user/ } \\
\text { non-user }\end{array} \\
\text {. }\end{array}$ & $\begin{array}{c}\text { Sample } \\
\text { size }\end{array}$ & Types of ADD & Disease stage & $\begin{array}{c}\mathrm{F} / \mathrm{U} \\
\text { (months) }\end{array}$ & $\begin{array}{c}\begin{array}{c}\text { Survival } \\
\text { endpoints }\end{array} \\
\text { ent }\end{array}$ & Adjusted variables \\
\hline Reni, 2016 & Italy & $\begin{array}{l}\text { Open Label, Randomized } \\
\text { Phase II Trial }\end{array}$ & Hospital-based & Single & $2010-2014$ & RCT & $\begin{array}{l}\text { Adverse event } \\
\text { review }\end{array}$ & $31 / 29$ & 60 & metformin & IV & $\mathrm{NR}$ & OS, PFS & NR \\
\hline Lee, 2016 & Korea & Retrospective cohort & Hospital-based & Single & $2005-2013$ & \begin{tabular}{|l|}
$\begin{array}{l}\text { self-reported medical } \\
\text { records }\end{array}$
\end{tabular} & $\begin{array}{l}\text { Medical record } \\
\text { review }\end{array}$ & $117 / 120$ & 1339 & \begin{tabular}{|l} 
Metformin \\
TZDS \\
SU \\
Insulin \\
\end{tabular} & I-IV & $\begin{array}{c}\text { Median } \\
10.3\end{array}$ & os & $\begin{array}{l}\text { Serum CA19-9 } \\
\text { levels, tumor size, tail involvement, } \\
\text { performance status, cancer stage, use of } \\
\text { DDP4 inhibitors }\end{array}$ \\
\hline Kozak, 2016 & USA & Retrospective cohort & Hospital-based & Single & $1998-2013$ & $\begin{array}{l}\text { electronic medical } \\
\text { record }\end{array}$ & $\begin{array}{l}\text { Medical record } \\
\text { review }\end{array}$ & $18 / 153$ & 201 & metformin & IHIV & $\begin{array}{c}\text { Median } \\
11.23\end{array}$ & OS, DFS & 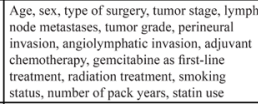 \\
\hline Choi, 2016 & Korea & Retrospective cohort & Hospital-based & Single & 2003-2010 & $\begin{array}{l}\begin{array}{l}\text { electronic medical } \\
\text { record }\end{array} \\
\end{array}$ & NR & $56 / 127$ & 349 & $\begin{array}{l}\text { Metformin } \\
\text { SU } \\
\text { Insulin }\end{array}$ & I-IV & $\begin{array}{c}\text { Median } \\
10.2\end{array}$ & os & $\begin{array}{l}\text { Performance status, } \\
\text { DM status, cancer extent, and weight loss } \\
\text { during first-line therapy }\end{array}$ \\
\hline Chaiteerakij, 2016 & USA & Retrospective cohort & Hospital-based & Single & $2000-2011$ & $\begin{array}{l}\text { electronic medical } \\
\text { record }\end{array}$ & NR & $366 / 614$ & 2,964 & metformin & $\mathrm{I}-\mathrm{IV}$ & $\begin{array}{c}\text { Median } \\
16.5\end{array}$ & os & $\begin{array}{l}\begin{array}{l}\text { Age, Sex, Region, Charlson comorbidity } \\
\text { index, Treatment regimen }\end{array} \\
\end{array}$ \\
\hline Cerull, 2016 & USA & Retrospective cohort & Population-based & Multiple & $2010-2012$ & \begin{tabular}{|l} 
Electronic medical \\
record
\end{tabular} & patient records & $456 / 2937$ & 3393 & metformin & I-IV & $\begin{array}{c}\text { Median } \\
16.5\end{array}$ & os & \begin{tabular}{|l|}
$\begin{array}{l}\text { Agc,Sex,Region,Charlson comorbidity } \\
\text { index,Treatment regimen }\end{array}$ \\
\end{tabular} \\
\hline Ambe, 2016 & USA & Prospective cohort & Hospital-based & Single & $1986-2013$ & $\begin{array}{l}\text { electronic medical } \\
\text { record }\end{array}$ & $\begin{array}{l}\text { medical record } \\
\text { revicw of the } \\
\text { social security } \\
\text { death index }\end{array}$ & $19 / 25$ & 44 & metformin & I-HI & Median 19 & os & $\begin{array}{l}\text { Margin status, regional nodes examined, } \\
\text { number of fregional nodes positive, age at } \\
\text { diagnosis, BMI, type of surgery, diabetes } \\
\text { duration, CA199 grade, stage }\end{array}$ \\
\hline Mathews, 2015 & Netherlands & RCT & Hospital-based & Multiple & 2010-2014 & RCT & $\begin{array}{l}\text { Adverse event } \\
\text { review }\end{array}$ & $61 / 60$ & 121 & metformin & IV & $\begin{array}{c}\text { Median } \\
28.1\end{array}$ & OS, PFS & 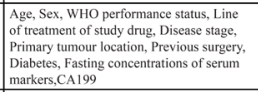 \\
\hline Tseng, 2013 & Taiwan & Retrospective cohort & Population-based & Multiple & 1995-2006 & \begin{tabular}{|l} 
structured \\
questionnaire \\
interview
\end{tabular} & $\begin{array}{l}\text { The national } \\
\text { death certificate }\end{array}$ & $5927 / 80970$ & 86897 & insulin & I-IV & $\begin{array}{c}\text { Up to } 12 \\
\text { years }\end{array}$ & os & $\begin{array}{l}\text { Age, sex, diabetes duration, body mass } \\
\text { index, smoking, insulin use, area of } \\
\text { residence }\end{array}$ \\
\hline Hwang, 2013 & $\begin{array}{l}\text { United } \\
\text { Kingdom }\end{array}$ & Retrospective cohort & Population-based & Multiple & 2003-2010 & $\begin{array}{l}\text { electronic medical } \\
\text { record }\end{array}$ & $\begin{array}{l}\text { the exact date } \\
\text { of death in the } \\
\text { THIN database. }\end{array}$ & $247 / 269$ & 516 & metformin & I-IY & NR & os & $\begin{array}{l}\text { Age, sex, duration of diabetes, presencec } \\
\text { of diabetic complications, history of } \\
\text { pancreatitis, Charlson index, BMI, GFR, } \\
\text { smoking at the } \\
\text { Time of diagnosis, history of insulin use, } \\
\text { history of sulfonylurea use, history of } \\
\text { thiazolidinedione use, and HbAlc. }\end{array}$ \\
\hline Sadeghi, 2012 & USA & Retrospective cohort & Hospital-based & Single & 2000-2009 & \begin{tabular}{|l|}
$\begin{array}{l}\text { personal interviews, } \\
\text { medical record } \\
\text { review. }\end{array}$ \\
\end{tabular} & NR & $117 / 185$ & 302 & metformin & I-IV & $\begin{array}{c}\text { Median } \\
11.4\end{array}$ & os & $\begin{array}{l}\text { Disease stage, serum CA-199 level,tumor } \\
\text { size, tumor site, performance status, } \\
\text { metformin use }\end{array}$ \\
\hline Amin, 2015 & USA & Retrospective cohort & Population-based & Multiple & 2007-2011 & NR & NR & $589 / 258$ & 847 & metformin & I-IV & NR & os & $\begin{array}{l}\text { Demographic factors, stage, median income, } \\
\text { diabetic complilactions, severity, Charlson } \\
\text { comortidity score, other DM medications, } \\
\text { treatment }\end{array}$ \\
\hline Jang, 2016 & Korea & Prospective cohort & Population-based & Multiple & $2005-2011$ & \begin{tabular}{|l} 
prescription \\
information
\end{tabular} & NR & $530 / 234$ & 28862 & metformin & $\mathrm{I}-\mathrm{IV}$ & NR & os & NR \\
\hline Jeon, 2014 & USA & Retrospective cohort & Population-based & Multiple & 2008-2009 & NR & NR & $132 / 131$ & 263 & $\begin{array}{l}\text { insulin / } \\
\text { sulfonylurea; } \\
\text { metformin/TZD }\end{array}$ & I-IV & NR & os & $\begin{array}{l}\begin{array}{l}\text { Age, sex, race, stage at diagnosis and } \\
\text { chemonotherapy }\end{array} \\
\text {. }\end{array}$ \\
\hline
\end{tabular}

these three variables adjusted, a null prognostic association of metformin use was noted. Nevertheless, further studies should be conducted to examine the true survival benefit of metformin in PC patients due to the small number of studies involved in these subgroups.

Sensitivity analysis by omitting one single study each time and pooling the others indicated that the pooled HRs were not significantly altered. Funnel plot for publication bias did not show asymmetry (Figure 3). Further Egger's test $(P=0.135)$ or Begg's test $(P=0.436)$ also did not found a certain degree publication bias.

\section{Insulin and other ADD use and PC survival}

Five studies investigated the impact of insulin use and $\mathrm{PC}$ survival and there was no significant association between insulin use and PC survival (HR 1.18, 95\% CI 0.83 to 1.69$)$. We also did not find significant association between Su (HR 1.03, 95\% CI 0.81 to 1.30 ) or TZD (HR $0.84,95 \%$ CI 0.58 to 1.22 ) use and PC survival.

\section{DISCUSSION}

This meta-analysis aimed to investigate the association between ADD (metformin, insulin, SU and TZD) use and survival of PC. We found metformin use was associated with significantly favorable OS of PC patients (HR $0.77,95 \%$ CI 0.68 to 0.87 ) in cohort studies, but was not associated with significantly PFS (HR 1.22;
95\% CI 0.76 to 1.95 ) or for RCTs. We also found no survival benefits of other ADDs such as insulin, SU or TZD for PC patients.

Several potential mechanisms may explain the associations for the fact that conventional ADMs may alter the risk of multiple malignancies. It was reported that metformin plays an important anticancer role in multiple ways including insulin-dependent or independent manners [26]. A recent study found that sulfonylureas can induce cell proliferation and have an effect of carcinogenesis by promoting insulin secretion [27]. Moreover, previous in vitro studies showed that thiazolidinediones have an impact on cell growth arrest and apoptosis and the inhibition of cancer cell invasion [28].

Several important strengths of this meta-analysis should be addressed. Firstly, to the best of our knowledge, this is the first systematic review regarding the associations between the use of ADMs and prognosis of PCs. Secondly, a comprehensive and reproducible search strategies were developed to identify all relevant studies or trials in the major databases without language limitations. Thirdly, we included the most commonly used ADDs including metformin, Su, TZDs and insulin for analysis and involved both RCTs and cohort studies. Fourthly, more than 120000 participants were included to quantitatively assess the association between ADDs use and $\mathrm{PC}$ prognosis, which was the most comprehensive synthesis of the evidence on this topic ever today. Finally, several subgroup analyses were carried out for some of the important variables, 
Table 2: Subgroup analyses of the associations between $A D D$ use and survival for PC patients

\begin{tabular}{|c|c|c|c|c|c|}
\hline Metformin/OS & HR & $95 \% \mathrm{CI}$ & $\begin{array}{c}\text { Degree of } \\
\text { heterogeneity } \\
\left(I^{2} \text { statistics; \%) }\right.\end{array}$ & $\begin{array}{l}\text { No. of included } \\
\text { Studies }\end{array}$ & $P$ for interaction \\
\hline Total & 0.77 & 0.68 to 0.87 & 52.9 & 11 & NA \\
\hline Study design & & & & & 0.534 \\
\hline Prospective cohort & 0.72 & 0.61 to 0.86 & 0 & 2 & \\
\hline Retrospective cohort & 0.78 & 0.67 to 0.90 & 58.9 & 9 & \\
\hline Study setting & & & & & 0.111 \\
\hline Hospital based & 0.67 & 0.53 to 0.85 & 64.5 & 6 & \\
\hline Population based & 0.84 & 0.73 to 0.96 & 33.6 & 5 & \\
\hline Study region & & & & & 0.0257 \\
\hline USA & 0.78 & 0.67 to 0.92 & 47.2 & 7 & \\
\hline Europe & 1.09 & 0.80 to 1.48 & & 1 & \\
\hline Asia & 0.69 & 0.60 to 0.79 & 0 & 3 & \\
\hline Hospital number & & & & & 0.111 \\
\hline Single & 0.67 & 0.53 to 0.85 & 64.5 & 6 & \\
\hline Multiple & 0.84 & 0.73 to 0.96 & 33.6 & 5 & \\
\hline Sample size & & & & & 0.036 \\
\hline$\geq 500$ & 0.83 & 0.72 to 0.95 & 59.1 & 6 & \\
\hline$<500$ & 0.64 & 0.53 to 0.78 & 0 & 5 & \\
\hline Main variable adjusted* & & & & & 0.276 \\
\hline Yes & 0.83 & 0.68 to 1.03 & 57.8 & 5 & \\
\hline No & 0.73 & 0.64 to 0.83 & 30.8 & 6 & \\
\hline NOS scale & & & & & 0.359 \\
\hline$\geq 8$ & 0.73 & 0.59 to 0.90 & 59.4 & 6 & \\
\hline$<8$ & 0.82 & 0.71 to 0.94 & 36.2 & 5 & \\
\hline OS & HR & $95 \% \mathrm{CI}$ & $\begin{array}{c}\text { Degree of } \\
\text { heterogeneity } \\
\left(I^{2} \text { statistics; \%) }\right.\end{array}$ & $\begin{array}{l}\text { No. of included } \\
\text { Studies }\end{array}$ & \\
\hline Insulin & 1.18 & 0.83 to 1.69 & 69 & 5 & \\
\hline $\mathrm{Su}$ & 1.03 & 0.81 to 1.30 & 17.9 & 2 & \\
\hline TZD & 0.84 & 0.58 to 1.22 & 0 & 2 & \\
\hline RCT-metformin & 1.2 & 0.84 to 1.72 & 15.3 & 2 & \\
\hline PFS-metformin & 1.22 & 0.76 to 1.95 & 52.8 & 3 & \\
\hline
\end{tabular}

Abbreviations: ADDs, anti-diabetic drugs; PC, pancreatic cancer; CI, confidence interval; het, heterogeneity; HR, hazard ratio; NA, not available; $\mathrm{SU}$, sulfonylureas; TZD, thiazolidinedione.

such as study design and setting, research region, number of research hospital, main variable adjusted and quality score. The results showed consistency across subgroups.

Still there are limitations in our systematic review. Firstly, the number of studies for each medication involved in this meta-analysis was relatively small except for metformin, and thus it is difficult to draw definite conclusions for the limited statistical power in Su, TZDs or insulin subset. Secondly, we did not assess dose or duration-response relationship in our meta-analysis as most of the included studies had no dose or duration information for abstraction, so it is impossible for us to perform this kind of analysis. Therefore, further study should be focused on this aspect. Thirdly, although some known major confounders including age, sex and disease stage were identified and adjusted for some of the included studies, some other variables (such as tumor size, body mass index or chemotherapy) could influence our exploration 
of associations between ADDs and PC survival. We also noted that two of the included studies provided only unadjusted HRs using univariate analysis [15, 18], which would to some extent influence the results though the sensitivity analysis did not show the change in the pooled estimates. Moreover, although we did not find significant publication bias for metformin subset in cohort studies, we could not totally exclude potantial impact of unpublished studies on the pooled results, which might have resulted in reporting bias. And the adjusted estimates of the results

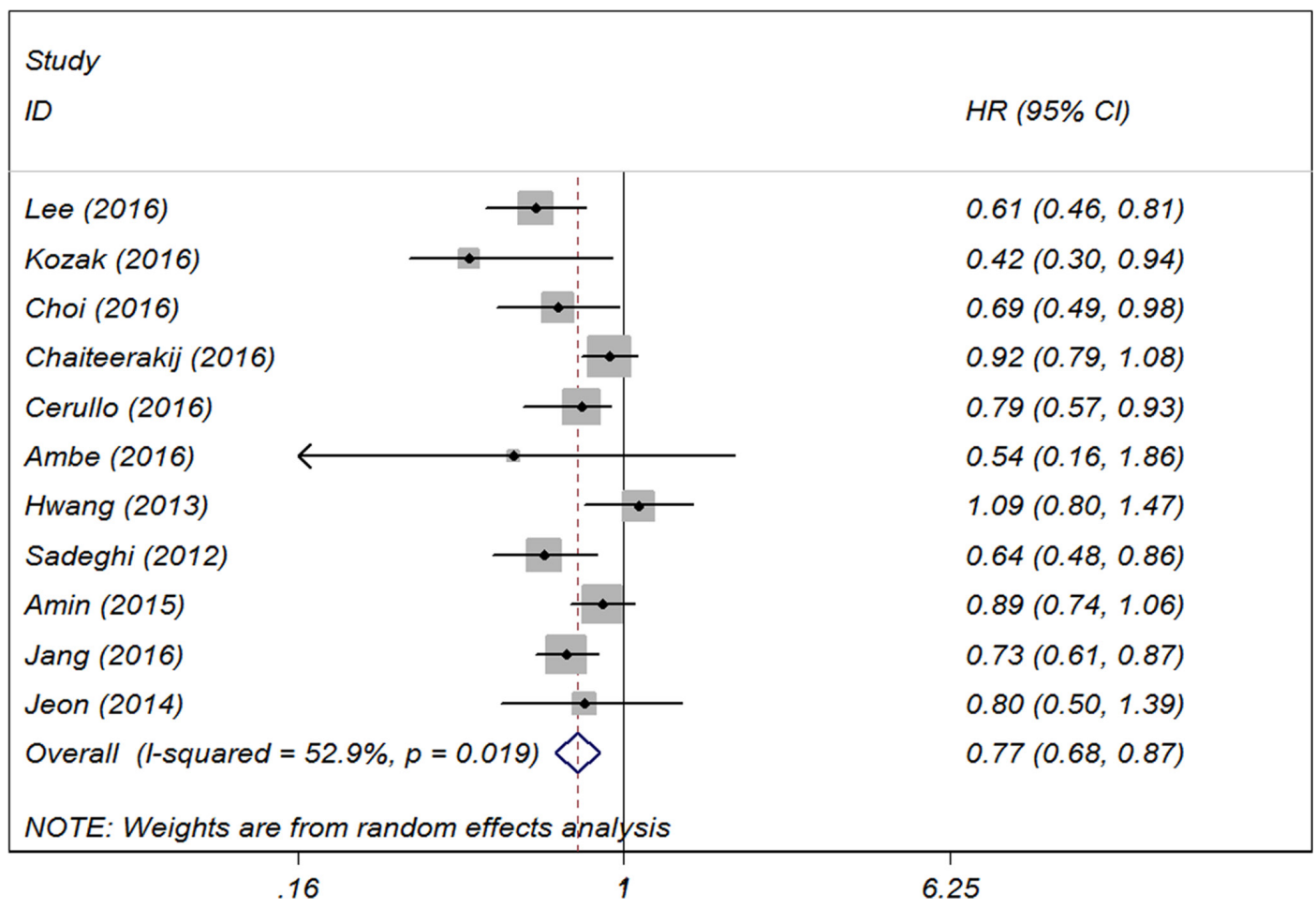

Figure 2: Association between metformin intake and overall survival for pancreatic cancer patients.

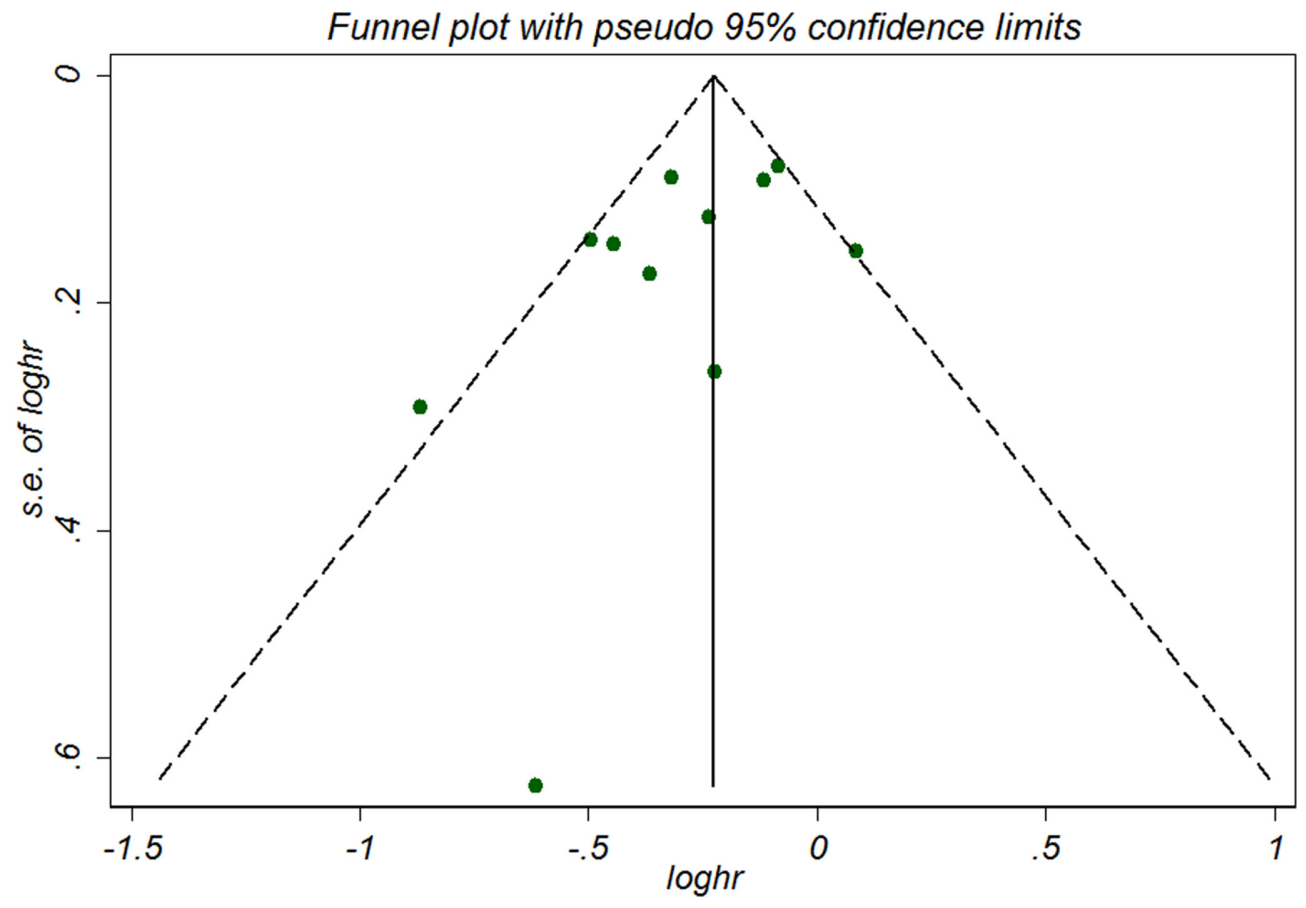

Figure 3: Funnel plot for meta-analysis of the association between metformin intake and overall survival for pancreatic cancer patients. 
using the trim and fill methods remained unchanged, indicating the stable of our analysis. Finally, as rare studies included data regarding prediagnosis or postdiagnosis ADD use, the included studies generally defined ADD exposure as use of ADDs during the peridiagnosis period regardless of the prediagnosis and postdiagnosis exposure. So it is impossible for us to perform this kind of analysis. However, two studies reported that the initiation of metformin after cancer diagnosis did not improve survival for patients with PC $[11,19]$.

The survival benefit of metformin was seen mainly in cohort studies, which accounted for most of the included studies $(12 / 14)$ and sample size $(12,037 / 12,6158)$. As for study design, the patients included in RCTs were likely to have a low risk of cancer mortality or progression which were both performed in the Western countries (Italty and Netherlands). Moreover, the survival impact of metformin in cohort studies might also represent an overestimate of its true effect in that cohort studies would not have the random allocation process to examine exposure-outcome hypotheses optimally. Despite adjusting for potential covariates, there remained to be numerous potential residual confounders. For example, diabetic patients of these studies usually used mutiple ADDs simultaneously. Therefore, other ADDs may also have a cancer-modifying effect on patient survival, which may overestimate the survival effect of metformin.

The current meta-analysis provides evidence that metformin reduces the risk of all-cause mortality for PC patients and therefore reinforces previous concerns regarding the real world survival effect of metformin for type 2 diabetes. Based on the findings of this study, we suggest the following avenues for further study. The first is to investigate the pragmatic real world effectiveness of metformin intervention for PC patients through controlled clinical trials or RCTs. The second avenue for further study is to conduct the population level meta-analysis based on large-scale population based cohort studies.

To sum up, the results from this meta-analysis revealed that in cohort studies, metformin, not other ADDs is associated with impoved OS in PC patients; however, due to limited number of studies invstigating other ADDs except metformin, further large-scale studies are warranted to determine this associations.

\section{MATERIALS AND METHODS}

\section{Literature search and study selection}

Based on the PRISMA statement [29], we performed a comprehensive literature search in PUBMED and EMBASE databases up to September 2016 for relevant citations without language restrictions. We used the search strategies (Supplementary Tables 1-2) that included Medical Subject Headings and Emtree headings combined key words relating to the prognostic effect of
ADDs among PC patients. We also manually scanned the reference lists from the extracted relevant research papers, previous reviews and meta-analysis for additional possible publications. Unpublished studies or data were not included due to insufficient information obatained.

We included published studies providing aggregate data if they met the following criteria: (1) evaluated any prognostic information in PC patients comparing ADDs users with non-users, (2) reported a summary statistic of HRs with $95 \%$ CIs or provided date for calculation as described by Parmar et al.[30]. We defined ADD exposure as use of ADDs during the peridiagnosis period regardless of the prediagnosis and postdiagnosis exposure. RCTS or observational studies were eligible for this meta-analysis. If there were more than one studies from the same cohort, we selected the most detailed or recent one for analysis. All the studies reporting prognostic information, including OS, and PFS. were selected in the main analyses. Two independent investigators (L.Z. and S.Y.) conducted study selection from eligible studies.

\section{Data extraction and quality assessment}

Two independent investigators (L.Z. and S.Y.) selected articles and extracted data from eligible studies, evaluated the quality of each study and any discrepancies were resolved by a consensus discussion with a third investigator (H.B.). The characteristics recorded were the study author, study publication year, research country, study design and setting, involved centers, enrolled period of study, information source for exposure ascertainment and outcome assessment, sample size in exposed and nonexposed group, sample size, type of ADDs, tumor stage, mean follow-up period, survival endpoints and adjustment variables. The methodological quality of each study was evaluated using the Newcastle-Ottawa quality assessment scale [31], in which three domains including cohort selection, comparability, and outcome were evaluated with a score range from 0 to 9 , with 9 representing the highest quality and 0 the lowest.

\section{Statistical analyses}

STATA software (version 12.0, StataCorp LP, College Station, TX) was used to perform the metaanalysis. Survival estimates with full adjustments for known confounders of included studies were abstracted. Summary data reporting HRs with corresponding 95\% CIs estimated from Cox proportional hazards models were pooled with random-effects model [32]. The data regarding the association of ADDs (use vs. no use) with survival outcomes were pooled separately. We used the Cochrane Q statistic (with a $P$ value less than 0.10 considering statistically significant) and the $\mathrm{I}^{2}$ statistic (with an $\mathrm{I}^{2}$ exceeding 50\% indicating significant heterogeneity) to test for between-study heterogeneity [33]. OS for metformin 
was explored as the primary outcome measure. Other outcome measure such as progression-free survival (PFS) was also evaluated. We performed sensitivity analyses to explore the reasons for statistical heterogeneity.The risk of publication bias was assessed visually by inspecting of a funnel plot and statistically by using Egger's or Begg's regression model $[34,35]$. We further ascertained the number of missing studies using Duval and Tweedie's trim and fill method to adjust the summary hazard ratio based on all the studies including the hypothesized missing ones [36]. All statistical analyses were two-sided and a $P$ value less than 0.05 was considered significant.

\section{CONFLICTS OF INTEREST}

The authors declare no potential conflicts of interest.

\section{GRANT SUPPORT}

None.

\section{REFERENCES}

1. Ferlay J, Partensky C, Bray F. More deaths from pancreatic cancer than breast cancer in the EU by 2017. Acta oncologica (Stockholm, Sweden). 2016; 55:1158-1160.

2. Siegel R, Naishadham D, Jemal A. Cancer statistics, 2012. CA: a cancer journal for clinicians. 2012; 62:10-29.

3. Hidalgo M. Pancreatic cancer. The New England journal of medicine. 2010; 362:1605-1617.

4. Raimondi S, Maisonneuve P, Lowenfels AB. Epidemiology of pancreatic cancer: an overview. Nature reviews Gastroenterology \& hepatology. 2009; 6:699-708.

5. Hassan MM, Bondy ML, Wolff RA, Abbruzzese JL, Vauthey JN, Pisters PW, Evans DB, Khan R, Chou TH, Lenzi R, Jiao L, Li D. Risk factors for pancreatic cancer: case-control study. The American journal of gastroenterology. 2007; 102:2696-2707.

6. Ben Q, Xu M, Ning X, Liu J, Hong S, Huang W, Zhang H, Li Z. Diabetes mellitus and risk of pancreatic cancer: A meta-analysis of cohort studies. European journal of cancer (Oxford, England : 1990). 2011; 47:1928-1937.

7. Grouven U, Hemkens LG, Bender R, Sawicki PT. Risk of malignancies in patients with diabetes treated with human insulin or insulin analogues. Reply to Nagel JM, Mansmann U, Wegscheider K et al. [letter] and Simon D [letter]. Diabetologia. 2010; 53:209-211.

8. Libby G, Donnelly LA, Donnan PT, Alessi DR, Morris AD, Evans JM. New users of metformin are at low risk of incident cancer: a cohort study among people with type 2 diabetes. Diabetes care. 2009; 32:1620-1625.

9. Currie CJ, Poole CD, Gale EA. The influence of glucoselowering therapies on cancer risk in type 2 diabetes. Diabetologia. 2009; 52:1766-1777.
10. Choi Y, Kim TY, Oh DY, Lee KH, Han SW, Im SA, Kim TY, Bang YJ. The Impact of Diabetes Mellitus and Metformin Treatment on Survival of Patients with Advanced Pancreatic Cancer Undergoing Chemotherapy. Cancer research and treatment : official journal of Korean Cancer Association. 2016; 48:171-179.

11. Cerullo M, Gani F, Chen SY, Canner J, Pawlik TM. Metformin Use Is Associated with Improved Survival in Patients Undergoing Resection for Pancreatic Cancer. Journal of gastrointestinal surgery. 2016; 20:1572-1580.

12. Ambe CM, Mahipal A, Fulp J, Chen L, Malafa MP. Effect of Metformin Use on Survival in Resectable Pancreatic Cancer: A Single-Institution Experience and Review of the Literature. PloS one. 2016; 11:e0151632.

13. Kuuselo R, Savinainen K, Azorsa DO, Basu GD, Karhu R, Tuzmen S, Mousses S, Kallioniemi A. Intersex-like (IXL) is a cell survival regulator in pancreatic cancer with 19q13 amplification. Cancer research. 2007; 67:1943-1949.

14. Asano T, Yao Y, Shin S, McCubrey J, Abbruzzese JL, Reddy SA. Insulin receptor substrate is a mediator of phosphoinositide 3-kinase activation in quiescent pancreatic cancer cells. Cancer research. 2005; 65:9164-9168.

15. Reni M, Dugnani E, Cereda S, Belli C, Balzano G, Nicoletti R, Liberati D, Pasquale V, Scavini M, Maggiora P, Sordi V, Lampasona V, Ceraulo D, et al. (Ir)relevance of Metformin Treatment in Patients with Metastatic Pancreatic Cancer: An Open-Label, Randomized Phase II Trial. Clinical cancer research. 2016; 22:1076-1085.

16. Lee SH, Yoon SH, Lee HS, Chung MJ, Park JY, Park SW, Song SY, Chung JB, Bang S. Can metformin change the prognosis of pancreatic cancer? Retrospective study for pancreatic cancer patients with pre-existing diabetes mellitus type 2. Digestive and liver disease. 2016; 48:435-440.

17. Kozak MM, Anderson EM, von Eyben R, Pai JS, Poultsides GA, Visser BC, Norton JA, Koong AC, Chang DT. Statin and Metformin Use Prolongs Survival in Patients With Resectable Pancreatic Cancer. Pancreas. 2016; 45:64-70.

18. Jang WI, Kim MS, Kang SH, Jo AJ, Kim YJ, Tchoe HJ, Park CM, Kim HJ, Choi JA, Choi HJ, Paik EK, Seo YS, Yoo HJ, et al. Association between metformin use and mortality in patients receiving curative resection for pancreatic cancer: A nationwide population-based study. Liver Cancer. 2016; 5:75.

19. Chaiteerakij R, Petersen GM, Bamlet WR, Chaffee KG, Zhen DB, Burch PA, Leof ER, Roberts LR, Oberg AL. Metformin Use and Survival of Patients With Pancreatic Cancer: A Cautionary Lesson. Journal of clinical oncology. 2016; 34:1898-1904.

20. Mathews CE, Kordes S, Pollak MN, Zwinderman AH, Mathot RA, Weterman MJ, Beeker A, Punt CJ, Richel DJ, Wilmink JW. Metformin in patients with advanced pancreatic cancer: a double-blind, randomised, placebocontrolled phase 2 trial. American journal of physiology Regulatory, integrative and comparative physiology. 2015; 16:839-847. 
21. Amin S, Mhango G, Lin J, Boffetta P, Wisnivesky J, Lucas A. Metformin use does not improve survival among diabetics with pancreatic adenocarcinoma: A populationbased analysis. American Journal of Gastroenterology. 2015; 110:S17.

22. Jeon CY, Pandol SJ, Goodman MT. Survival time in pancreatic cancer patients with metabolic syndrome varies by use of insulin and statins. Cancer research. 2014; 74.

23. Tseng CH. Diabetes, insulin use, smoking, and pancreatic cancer mortality in Taiwan. Acta diabetologica. 2013; 50:879-886.

24. Hwang AL, Haynes K, Hwang WT, Yang YX. Metformin and survival in pancreatic cancer: a retrospective cohort study. Pancreas. 2013; 42:1054-1059.

25. Sadeghi N, Abbruzzese JL, Yeung SC, Hassan M, Li D. Metformin use is associated with better survival of diabetic patients with pancreatic cancer. Clinical cancer research : an official journal of the American Association for Cancer Research. 2012; 18:2905-2912.

26. Gallagher EJ, LeRoith D. Diabetes, cancer, and metformin: connections of metabolism and cell proliferation. Annals of the New York Academy of Sciences. 2011; 1243:54-68.

27. Bowker SL, Majumdar SR, Veugelers P, Johnson JA. Increased cancer-related mortality for patients with type 2 diabetes who use sulfonylureas or insulin. Diabetes care. 2006; 29:254-258.

28. Okumura T. Mechanisms by which thiazolidinediones induce anti-cancer effects in cancers in digestive organs. Journal of gastroenterology. 2010; 45:1097-1102.
29. Liberati A, Altman DG, Tetzlaff J, Mulrow C, Gotzsche PC, Ioannidis JP, Clarke M, Devereaux PJ, Kleijnen J, Moher D. The PRISMA statement for reporting systematic reviews and meta-analyses of studies that evaluate health care interventions: explanation and elaboration. Annals of internal medicine. 2009; 151:W65-94.

30. Parmar MK, Torri V, Stewart L. Extracting summary statistics to perform meta-analyses of the published literature for survival endpoints. Statistics in medicine. 1998; 17:2815-2834.

31. Stang A. Critical evaluation of the Newcastle-Ottawa scale for the assessment of the quality of nonrandomized studies in meta-analyses. Eur J Epidemiol. 2010; 25:603-605.

32. DerSimonian R, Laird N. Meta-analysis in clinical trials. Controlled clinical trials. 1986; 7:177-188.

33. Higgins JP, Thompson SG. Quantifying heterogeneity in a meta-analysis. Statistics in medicine. 2002; 21:1539-1558.

34. Egger M, Davey Smith G, Schneider M, Minder C. Bias in meta-analysis detected by a simple, graphical test. BMJ (Clinical research ed). 1997; 315:629-634.

35. Begg CB, Mazumdar M. Operating characteristics of a rank correlation test for publication bias. Biometrics. 1994; 50:1088-1101.

36. Duval S, Tweedie R. Trim and fill: A simple funnel-plotbased method of testing and adjusting for publication bias in meta-analysis. Biometrics. 2000; 56:455-463. 